\title{
Effects of Stocking Rate and Heather Supplementation on Gastrointestinal Nematode Infections and Host Performance in Naturally-Infected Cashmere Goats
}

\author{
Koldo Osoro, ${ }^{1}$ Rafael Celaya, ${ }^{2}$ Javier Moreno-Gonzalo, ${ }^{3}$ Luis M. M. Ferreira, ${ }^{4}$ Urcesino Garcia, ${ }^{5}$ \\ Pilar Frutos, ${ }^{6}$ Luis M. Ortega-Mora, ${ }^{7}$ and Ignacio Ferre ${ }^{7}$
}

Authors are ${ }^{1}$ Research Leader, ${ }^{2}$ Research Associate, and ${ }^{5}$ Experimental Farm Manager, Área de Sistemas de Producción Animal, Servicio Regional de Investigación y Desarrollo Agroalimentario, 33300 Villaviciosa, Asturias, Spain; ${ }^{3}$ Graduate Student, and ${ }^{7}$ Professors, Salud Veterinaria y Zoonosis, Departamento de Sanidad Animal, Facultad de Veterinaria, Universidad Complutense de Madrid, Ciudad Universitaria s/n, 28040 Madrid, Spain; ${ }^{4}$ Professor, Centro de Ciencia Animal e Veterinaria, Departamento de Zootecnia, Universidade de Trás-os-Montes e Alto Douro, PO Box 1013, 5000-911 Vila Real, Portugal; and ${ }^{6}$ Research Associate, Estación Agrícola Experimental, Consejo Superior de Investigaciones Científicas, Finca Marzanas, 24346 León, Spain

\begin{abstract}
The aim of this study, performed on 62 adult dry cashmere goats grazing upland perennial ryegrass-white clover pastures and naturally infected with gastrointestinal nematodes, was to investigate the effects of stocking rate (SR: $24 \mathrm{vs.} 38$ goats $\cdot$ ha $^{-1}$ ) and tannin-containing heather supplementation (H: Calluna vulgaris [L.] Hull, Erica spp.) vs. nonsupplementation on parasite burden, fecal egg counts (FEC), and live weight (LW) changes. Goats were randomly assigned to four treatments in a $2 \times 2$ factorial arrangement and grazed continuously from May to October. Six goats per treatment were slaughtered at the end of the grazing period, and adult worms in the abomasum and small and large intestines of each animal were recovered, counted, and identified. FEC was affected by SR $(P<0.01)$ but not by H. However, the SR $\times \mathrm{H}$ interaction was significant $(P<0.05)$. FEC increased $(P<0.001)$ along the grazing season in all treatments, and the $\mathrm{SR} \times$ time interaction was significant $(P<0.001)$. In general, mean total worm counts in abomasum and small intestine tended to be higher under high SR, although the differences were only significant $(P<0.01)$ in Trichostrongylus spp. counts. In goats managed under the high SR, the mean of total Teladorsagia circumcincta counts was lower $(P<0.01)$ in supplemented animals, but no differences were recorded for Trichostrongylus spp., Chabertia ovina, Oesophagostomum columbianum, and Trichuris ovis. The goats gained more LW $(P<0.001)$ under low SR and when they were heather-supplemented. No significant $\mathrm{SR} \times \mathrm{H}$ interaction was found for $\mathrm{LW}$ change. In conclusion, high stocking rate increases the infectivity risk of pasture and the supplementation of grazing goats with heather contributing to improve animals' performance. Notwithstanding, the effect of heather availability on nematode FEC reduction could be highly dependent on the climatic conditions.
\end{abstract}

\section{Resumen}

Con el fin de estudiar el efecto de la carga animal (CA: 24 vs. 38 cabras/ha) y la suplementación con brezo (SB: Calluna vulgaris [L.] Hull, Erica spp.) vs. no brezo en las parasitosis por nematodos gastrointestinales del ganado caprino y su repercusión en las variaciones de peso, se manejaron 62 cabras cachemir adultas sin cría en pastoreo continuo de mayo a octubre en potreros de rye-grass y trébol blanco. Las cabras se distribuyeron en cuatro grupos según un diseño factorial $2 \times 2$. Al finalizar el pastoreo se sacrificaron seis cabras por tratamiento para contar el número de vermes en abomaso e intestino delgado y grueso, e identificarlos. El recuento fecal de huevos de nematodos fue afectado por la carga animal $(P<0.01)$, pero no por la suplementacion; sin embargo se encontró una interacción significativa $(P<0.05)$ entre $\mathrm{CA} \times \mathrm{SB}$. La cantidad de huevos se incrementó $(P<0.001)$ durante la estación de pastoreo en todos los tratamientos y la interacción $\mathrm{CA} \times$ Tiempo resultó significativa $(P<0.001)$. En general, el recuento de vermes en abomaso, intestino delgado y grueso tendió a ser mayor en los animales manejados en carga alta, aunque las diferencias fueron significativas $(P<0.01)$ solo para Trichostrongylus spp. En carga alta, la media total de Teladorsagia circumcincta fue menor $(P<0.01)$ en las cabras suplementadas, pero no se observaron diferencias para Trichostrongylus spp., Chabertia ovina, Oesophagostomum columbianum, y Trichuris ovis. Las ganancias de peso fueron mayores $(P<0.001)$ en las cabras en carga baja y en las suplementadas, no observándose interacción $\mathrm{CA} \times \mathrm{SB}$. En conclusión, en carga alta se observa un mayor riesgo de infección parasitaria, y la suplementación con brezo contribuye a mejorar las variaciones de peso de las cabras, aunque su efecto sobre los nematodos gastrointestinales podría depender de las condiciones climáticas.

Key Words: anthelmintic, grazing, live weight, parasite, tannin

Research was funded by the National Institute of Food and Agricultural Research of Spain under project RTA2007-00098-C03.

Correspondence: Koldo Osoro, Sistemas de Producción Animal, Servicio Regional de Investigación y Desarrollo Agroalimentario, Apdo. 13, 33300 Villaviciosa, Asturias, Spain. Email: kosoro@serida.org

Manuscript received 14 August 2008; manuscript accepted 9 December 2008.

\section{INTRODUCTION}

Conventional methods to control gastrointestinal nematode (GIN) infections of grazing ruminants widely have included the use of anthelmintic drugs. However, the resistance to all the major groups of broad-spectrum anthelmintics throughout the world (Jackson and Coop 2000) and the increasing demand by 
consumers for organic livestock products have prompted the investigation of alternative nonchemical control methods (Waller 2006). Stear et al. (2007) divided the possible nonchemical methods in five categories: grazing management, biological control, nutrition, vaccination, and genetic approaches. These authors indicated that no method can be recommended to the exclusion of all the others, and that there may be a role for a combination of methods.

Among grazing management methods, management decisions can modify the extent and severity of GIN infections (Morley and Donald 1980). Within these strategies, stocking rate, which affects sward height availability, is an intrinsic factor of the grazing systems that could be considered to be the main management factor also affecting biodiversity and systems sustainability (Milne and Osoro 1997). It commonly is assumed that increasing the stocking rate increases the level of parasitism in grazing animals. However, experimental evidence to support this view is rather limited in sheep, especially in temperate regions (Le Jambre 1984; Thamsborg et al. 1996), and is unknown in goats. The studies carried out in sheep (Thamsborg et al. 1996; Thamsborg and Hauge 2001) showed a very complex relationship between stocking rates and levels of infection by different parasites. Moreover, Osoro and Martínez (1995) observed that the percentage of improved pasture can affect parasite dynamics in goats managed on heathlands.

Within biological methods, a number of reports have been published in the last few years on the anthelmintic effects of tannin-rich plants on GIN infections in small ruminants (Hoste et al. 2006). In naturally infected goats, these studies showed a decrease in the establishment of third-stage nematode larvae or reductions in worm fertility and egg output when a moderate concentration of tannin-rich plants was consumed (Hoste et al. 2006; Shaik et al. 2006; Osoro et al. 2007b).

Surprisingly, there is a lack of research on the combination of different nonchemical methods, despite the idea that an integrated approach should achieve a better and more complete control of GIN infections (Barger 1999; Hoste et al. 2005, 2006). The objective of the present study therefore was to investigate the combination of two alternative methods: grazing management (stocking rate) and biological control (condensed tannins-heather supplementation) on GIN infections and animal performance in cashmere goats grazing upland perennial ryegrass-white clover pastures. The study was conducted under practical conditions in a less-favored area where grazing animals are extensively raised and included in the natural ecosystem dynamics.

\section{METHODS}

\section{Experimental Site}

The study was carried out in a mountainous area $(1000 \mathrm{~m}$ above sea level) in the northwest of Spain (lat $43^{\circ} 21^{\prime} \mathrm{N}$, long $6^{\circ} 53^{\prime} \mathrm{W}$, Sierra de San Isidro, Illano, Asturias), where shrubby heather-gorse vegetation is dominant. Four plots of $5000 \mathrm{~m}^{2}$ each were established in which the vegetation had been improved in 2001 by soil ploughing and dressing and sowing perennial ryegrass (Lolium perenne L.) and white clover (Trifolium repens L.).
Annual rainfall in the experimental year was $1253 \mathrm{~mm}$. During the grazing season, mean monthly rainfalls ranged from $11 \mathrm{~mm}$ in July to $166 \mathrm{~mm}$ in October. Mean average temperatures ranged from $11.3^{\circ} \mathrm{C}$ in May to $16.9^{\circ} \mathrm{C}$ in June.

\section{Goats}

A total of 62 adult nonlactating and nonpregnant cashmere goats, reared outdoors under pasture conditions not excluding GIN infections, were used in this study. The mean live weight (LW) of the goats at the beginning of the experiment was $31.2 \mathrm{~kg} \pm 0.88$ SE. Three weeks before the experiment started all goats were dosed orally with ivermectin (Oramec ${ }^{\mathrm{TM}}$, Merial, Lyon, France). The efficacy of the anthelmintic treatment was assessed at $21 \mathrm{~d}$ posttreatment by means of individual examination of fecal egg counts (FEC) and inspection of clinical signs to confirm that animals did not show patent infection.

The experiment was carried out in accordance with Spanish Royal Decree 1201/2005 for the protection of animals used for experimental and other scientific purposes.

\section{Experimental Design}

Sixty-two goats were balanced for LW and body condition and randomly assigned to one of four treatment groups in a $2 \times 2$ factorial arrangement. The main effects were two stocking rates $\left(24\right.$ vs. 38 goats $\cdot \mathrm{ha}^{-1}$ ) and two feeding treatments (supplementation with heather vs. nonsupplementation). Supplemented groups were offered freshly cut heather ad libitum in a cage in the field twice per week in the morning, whereas the others received no supplement. All goats grazed continuously throughout the whole experiment (there was not night confinement). The trial extended from 6 May to 21 October.

\section{Sampling Procedures}

Pasture. In order to control grass availability, sward surface height was measured weekly using a Hill Farming Research Organisation (HFRO) swardstick (Barthram 1986), with 100 measurements taken at random in each plot. The botanical composition of the pasture was assessed during the summer (21 July) using a point quadrat (Grant 1981) and recording 100 vertical hits at random in each plot.

Ash and nitrogen $(\mathrm{N})$ of pasture sampled in June, August, and October were analyzed following the procedures of the Association of Official Analytical Chemists (2006). Crude protein $(\mathrm{CP})$ was calculated as $\mathrm{N} \times 6.25$. Neutral and acid detergent fibre (NDF and ADF) and acid detergent lignin (ADL) were analyzed by the method of Goering and van Soest (1970) and van Soest et al. (1991).

Heather. The species composition of the heather offered to the goats was assessed in July by recording 1000 random contacts with the HFRO swardstick throughout the area where the heather was cut. Samples of the green shoots (less than $3 \mathrm{~mm}$ in diameter) of the heather offered to the goats were collected in June, August, and September for chemical composition. The nutritive quality (ash, $\mathrm{CP}, \mathrm{NDF}, \mathrm{ADF}$, and ADL) of the green shoots was analyzed following the same procedures mentioned for the pasture. Heather offered to the supplemented goats was also analyzed for total tannins using 
the Folin-Ciocalteu assay in combination with polyvinylpolypyrrolidone, as described by Makkar et al. (1993). Total tannin content was expressed as tannic acid equivalents.

Diet Selection. The percentage of heather in the diet of each individual goat was estimated on 19 August using the $n$-alkane method (Mayes et al. 1986), as modified by Oliván and Osoro (1999). Samples of pasture, heather, and feces from individual animals were collected, and calculations were performed using a least squares optimization procedure (Dove and Moore 1995), which minimizes the discrepancies between the actual concentration of alkanes in feces (adjusted for incomplete fecal recoveries, using the recovery values obtained in previous studies by Ferreira et al. 2005) and the estimated proportion in the diet.

Parasitological Procedures. Throughout the 6-mo trial, fecal samples were collected monthly from individual animals for FEC analysis. Feces were collected directly from the rectum, with ova counted using a modified McMaster procedure (Ministry of Agriculture, Fisheries, and Food [MAFF] 1978) with sodium chloride as the flotation medium, in which one egg counted is equivalent to 15 eggs per gram (epg) fresh feces. Fecal cultures were prepared monthly for each group by pooling samples from individual goats as described by MAFF (1978) to allow identification of third-stage nematode larvae genera according to van Wyk et al. (2004). In each sample 200 third-stage larvae were identified.

At the end of the trial, six goats of each treatment were slaughtered and adult worms were recovered from the abomasum and intestines. After slaughter, the abomasum and small and large intestines of each goat were ligated and opened, and the contents washed on a mesh screen $(60 \mu \mathrm{m})$ with tap water. For abomasum and small intestine, the contents were brought up to $500 \mathrm{~mL}$ with tap water and thoroughly mixed, and then one $10 \%$ aliquot $(50 \mathrm{~mL})$ was moved into $100-\mathrm{mL}$ storage containers. Approximately $100 \mathrm{~mL}$ of formalin $10 \%$ was added to each aliquot as a preservative. For both abomasal and small intestinal samples, the worms in the aliquot were washed on a mesh screen $(60 \mu \mathrm{m})$ with tap water, the formalin discarded, and the nematodes recovered into a $50 \mathrm{~mL}$ centrifuge tube. All large intestine contents were examined for GIN recovery. Afterwards, the nematodes were counted and identified according to species and sex using a phasecontrast microscope.

In order to assess the nematode development, the lengths of 20 male and 20 female worms of each species were measured using a microscope at $\times 10$ magnification. Fertility per female worm of each species was determined by direct counting of the eggs in utero after clearing of each female worm with lactophenol for Teladorsagia circumcincta and Trichostrongylus spp. according to the method described by Kloosterman et al. (1978) for Haemonchus contortus. Counts were performed on at least 20 female worms per goat.

Live Weight and Body Condition Score. All animals were weighed at the beginning and the end of the experimental grazing season and also at monthly intervals. At the same time, the body condition score (BCS) was assessed on a scale of 1 to 5 ( 1 =emaciated, 5 = fat; Russel 1990). To study LW changes and the possible relationship with FEC and heather percentage in the diet, the grazing season was divided into two periods: period 1 from the beginning to 19 August (high sward availability), and period 2 from 19 August until the end of the grazing season on 21 October (low sward availability).

\section{Statistical Analyses}

All analyses were performed using SAS System software (SAS Institute 1999). FEC data from individual animals were analyzed using a Mixed Model procedure (PROC MIXED) for repeated measures (Littell et al. 1998; Wang and Goonewardene 2004), including in the model the fixed effects of stocking rate (SR), heather supplementation $(\mathrm{H})$, sampling time ( $T$, with six repeated measures), and the interactions $\mathrm{SR} \times \mathrm{H}, \mathrm{SR} \times \mathrm{T}, \mathrm{H} \times \mathrm{T}$, and $\mathrm{SR} \times \mathrm{H} \times \mathrm{T}$, with the first measure in May as covariate.

Sward height data (plot means) were subjected to PROC MIXED, with 12 repeated measures in time (T) across the grazing season, examining the effects of stocking rate and heather supplementation independently, and the interactions $\mathrm{SR} \times \mathrm{T}$ or $\mathrm{H} \times \mathrm{T}$, respectively.

Data on goat LW and BCS changes in periods 1 and 2, and GIN measurements (parasite burden, sex ratio, fecundity in utero, body length) on euthanized goats at the end of the trial were analyzed with a General Linear Model procedure (PROC GLM) for the effects of the two main factors, SR and H, and their interaction. Pasture botanical composition in July (hit percentages from each plot) was analyzed by one-way analysis of variance (ANOVA) to test for SR or $\mathrm{H}$ effects independently. Diet composition of supplemented goats in August was analyzed by one-way ANOVA for the SR effect.

FEC data and worm counts were log transformed $\left(\log _{10} x+1\right)$ to normalize their distribution.

Correlation coefficients between heather percentage in the diet, FEC, and LW changes were analyzed using Spearman rank-order correlation. The mortality rate of goats in the different treatments was analyzed by chi-square test.

\section{RESULTS}

\section{Pasture}

Sward Height. Sward height achieved maximum values in June $(19.7 \mathrm{~cm}$ and $15.5 \mathrm{~cm}$ at low and high stocking rates, respectively) and decreased until August, remaining constant during period 2 (Fig. 1). Significant differences $(P<0.01)$ in the mean sward height across the grazing season were observed between low and high stocking rates $(11.2 \mathrm{~cm}$ and $9.2 \mathrm{~cm}$, respectively). The mean sward heights during period 1 were $13.4 \mathrm{~cm}$ under the low stocking rate and $11.2 \mathrm{~cm}$ under the high stocking rate. During period 2, the means were $7.7 \mathrm{~cm}$ and $6.2 \mathrm{~cm}$ under the low and high stocking rate, respectively. No significant differences in sward height were observed as a consequence of heather supplementation.

Botanical Composition. No significant differences were found in the sward composition, studied in July, between high and low stocking rates or between supplemented and nonsupplemented treatment plots. Green ryegrass accounted for a mean percentage of $27 \% \pm 1.0 \mathrm{SE}$, and the percentage of the native 


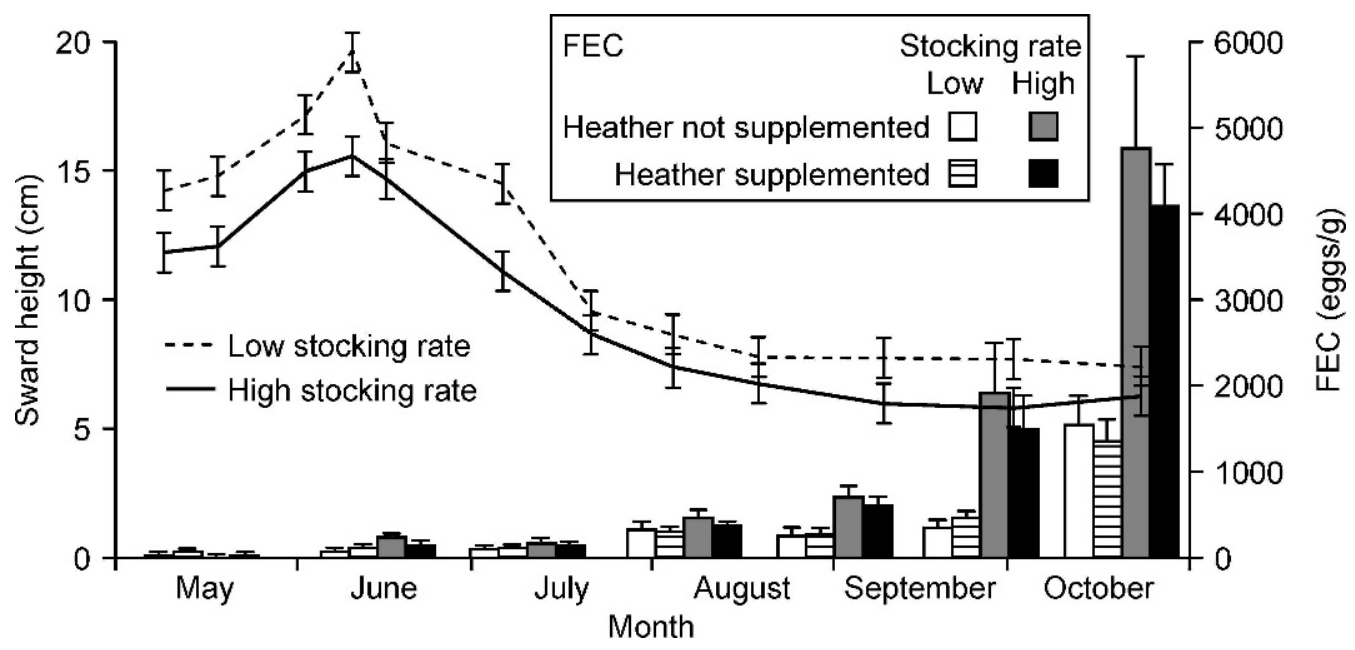

Figure 1. Sward height (means \pm SEM) during the experimental grazing period and fecal egg counts (FEC, means \pm SE) in goats grazing perennial ryegrass-white clover pastures under two stocking rates (Low: 24 goats $\cdot$ ha $^{-1}$, High: 38 goats $\cdot$ ha $^{-1}$ ) and supplemented or not with heather.

grass Agrostis capillaris L. was $26 \pm 3.9 \%$. White clover accounted for a mean of $4 \pm 1.2 \%$. The percentage of dead matter was high $(43 \pm 3.1 \%)$ as a consequence of the summer drought. The percentage of grass flower stems was also high $(21 \pm 2.5 \%)$ compared to the percentage of grass green foliage $(32 \pm 3.8 \%)$.

Chemical Composition. As shown in Table 1, pasture chemical composition changed from the beginning of the grazing period (June) to summer-autumn. The protein content decreased from $161 \mathrm{~g} \cdot \mathrm{kg}^{-1}$ dry matter (DM) to $118 \mathrm{~g} \cdot \mathrm{kg}^{-1}$ $\mathrm{DM}$, and the cell wall components (NDF and ADF) increased from $595 \mathrm{~g} \cdot \mathrm{kg}^{-1} \mathrm{DM}$ to $709 \mathrm{~g} \cdot \mathrm{kg}^{-1} \mathrm{DM}$ and from $288 \mathrm{~g} \cdot \mathrm{kg}^{-1} \mathrm{DM}$ to $389 \mathrm{~g} \cdot \mathrm{kg}^{-1} \mathrm{DM}$, respectively.

\section{Heather}

Botanical Composition. Among the offered heather species, $C$. vulgaris attained the highest percentage (57\%), and Erica umbellata L., Erica cinerea L., Erica tetralix L., and Daboecia cantabrica (Hudson) C. Koch accounted for 26\%, 13\%, 3\%, and $1 \%$, respectively.

Chemical Composition. Heather protein content during the experimental season ranged between $57 \mathrm{~g} \cdot \mathrm{kg}^{-1} \mathrm{DM}$ and $71 \mathrm{~g} \cdot \mathrm{kg}^{-1}$ DM (Table 1). Cell wall components did not change significantly along the experimental season, with the exception of NDF, which increased from August $\left(573 \mathrm{~g} \cdot \mathrm{kg}^{-1}\right.$
$\mathrm{DM})$ to September $\left(686 \mathrm{~g} \cdot \mathrm{kg} \mathrm{DM}{ }^{-1}\right)$. Tannin content ranged from $97 \mathrm{~g} \cdot \mathrm{kg}^{-1} \mathrm{DM}$ in June to $61 \mathrm{~g} \cdot \mathrm{kg}^{-1} \mathrm{DM}$ in August (Table 1).

\section{Diet Composition}

The proportion of heather in the diet of supplemented goats was not affected by the stocking rate $(0.201 \pm 0.023$ and $0.198 \pm 0.018$ for low and high stocking rate, respectively).

\section{Fecal Egg Counts and Coprocultures}

The FEC increased significantly $(P<0.001)$ across the grazing season and a significant $(P<0.01)$ interaction was found between stocking rate and time (Fig. 1). In September and October samplings, the animals from plots under the high stocking rate showed significantly $(P<0.01)$ higher mean FEC than those at the lower stocking rate. No differences in FEC were detected between goats supplemented with heather and nonsupplemented animals. However, a significant $(P<0.05)$ interaction was found between stocking rate and heather supplementation for the overall mean values across the grazing season.

Nematode genera, identified based on third-stage larvae obtained from coprocultures, were Teladorsagia, Trichostrongylus, and Chabertia (Fig. 2). Teladorsagia was the most frequently identified in June and July (60-93\%) in the four plots, decreasing sharply afterwards. In contrast, Trichostron-

Table 1. Chemical composition (mean $\pm \mathrm{SE}$ ) of pasture and heather across the grazing period.

\begin{tabular}{|c|c|c|c|c|c|c|}
\hline \multirow{2}{*}{$\begin{array}{l}\text { Chemical } \\
\text { composition } \\
\left(\mathrm{g} \cdot \mathrm{kg}^{-1} \mathrm{DM}\right)^{1}\end{array}$} & \multicolumn{3}{|c|}{ Pasture } & \multicolumn{3}{|c|}{ Heather } \\
\hline & June & August & October & June & August & September \\
\hline OM & $932 \pm 3.3$ & $957 \pm 15.0$ & $945 \pm 9.1$ & $977 \pm 0.3$ & $968 \pm 11.4$ & $977 \pm 7.9$ \\
\hline NDF & $595 \pm 51.2$ & $690 \pm 48.5$ & $709 \pm 27.0$ & $565 \pm 28.9$ & $573 \pm 5.3$ & $686 \pm 14.7$ \\
\hline $\mathrm{ADF}$ & $288 \pm 34.6$ & $389 \pm 52.6$ & $388 \pm 51.4$ & $508 \pm 10.8$ & $510 \pm 11.5$ & $506 \pm 9.8$ \\
\hline ADL & $35 \pm 8.4$ & $86 \pm 22.0$ & $61 \pm 13.5$ & $347 \pm 7.5$ & $333 \pm 15.7$ & $352 \pm 7.9$ \\
\hline $\mathrm{CP}$ & $161 \pm 28.1$ & $118 \pm 31.7$ & $123 \pm 20.1$ & $71 \pm 28.8$ & $71 \pm 2.9$ & $57 \pm 5.7$ \\
\hline Tannins $^{2}$ & & & & $97 \pm 5.9$ & $61 \pm 4.4$ & $79 \pm 4.9$ \\
\hline
\end{tabular}

${ }^{1}$ DM indicates dry matter; OM: organic matter; NDF: neutral detergent fibre; ADF: acid detergent fibre; ADL: acid detergent lignin; CP: crude protein.

${ }^{2}$ Expressed in tannic acid equivalents. 

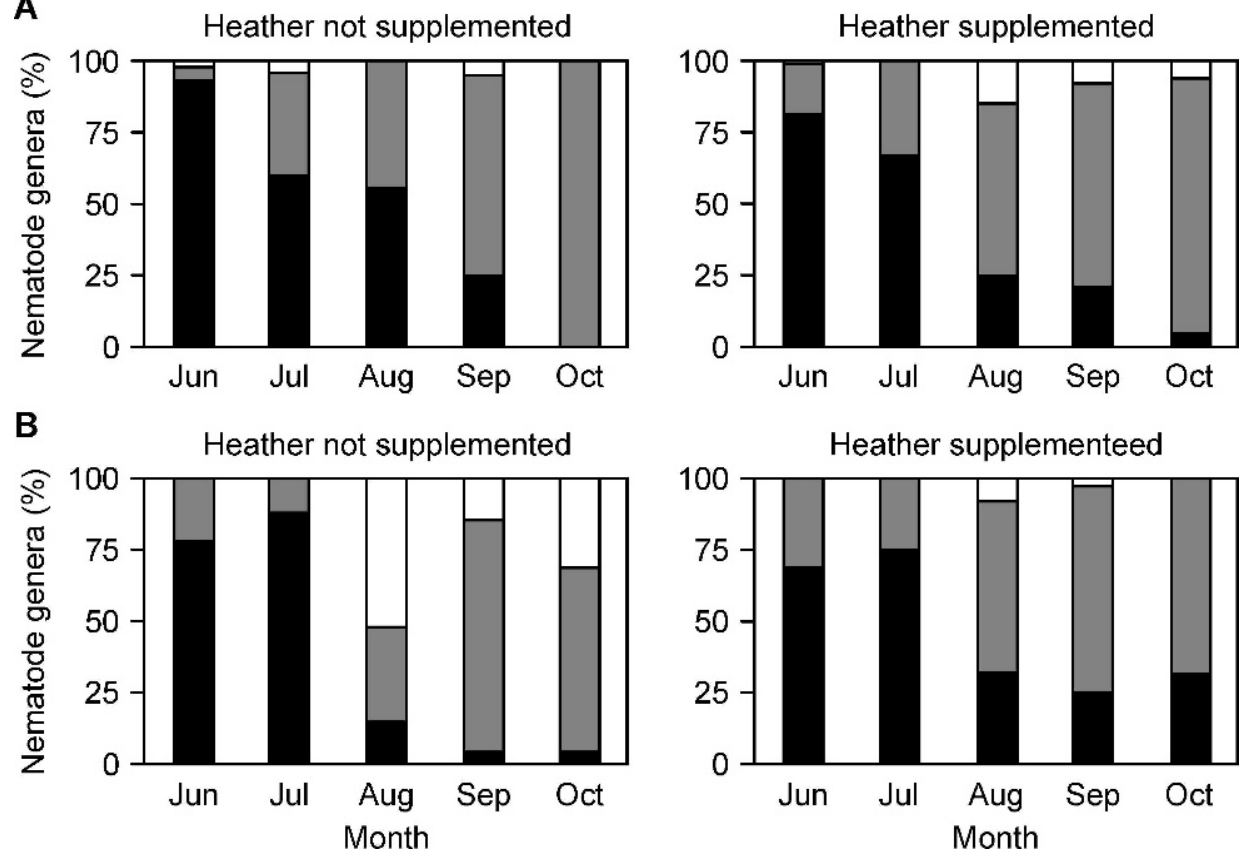

Figure 2. Nematode genera identified on third-stage larvae obtained in coprocultures from goats grazing perennial ryegrass-white clover pastures under two stocking rates and supplemented or not with heather. A, Low stocking rate $\left(24 \mathrm{goats} \cdot \mathrm{ha}^{-1}\right)$. B, High stocking rate $\left(38 \mathrm{goats} \cdot \mathrm{ha}^{-1}\right)$. Black, Teladorsagia; grey, Trichostrongylus; white, Chabertia.

gylus was predominant from August to October (33-100\%). Chabertia was detected in all plots but at a lower percentage $(0-31 \%)$, except in the August sampling of goats not supplemented with heather under the higher stocking rate $(52 \%)$.

\section{Adult Nematode Burden}

Table 2 shows the mean worm burden, sex ratio, and fecundity in utero of female nematodes. In general, mean total worm counts in abomasum and small intestine tended to be higher in animals from plots with 38 goats $\cdot \mathrm{ha}^{-1}$, although the differences only were significant $(P<0.01)$ for Trichostrongylus spp. counts. In plots with 38 animals $\cdot \mathrm{ha}^{-1}$, mean Teladorsagia circumcincta counts were significantly lower $(P<0.01)$ in goats supplemented with heather than in nonsupplemented animals. Teladorsagia trifurcata was also identified in some goats but with a very low prevalence rate $(<2 \%)$. Mean Trichostrongylus axei counts in goats from plots with 38 animals $\cdot \mathrm{ha}^{-1}$ were significantly higher $(P<0.01)$ when compared with goats under the lower stocking rate. Although Trichostrongylus colubriformis and T. vitrinus were identified in the small intestine on the basis of male identification, the results are shown together. No significant differences were found between treatments for large intestine worm counts, but Chabertia ovina was more numerous $(P<0.01)$ in nonsupplemented goats managed at the high stocking rate.

The female worm fertility (estimated by the numbers of eggs in utero; Table 2) and development (estimated by the total length; Table 3$)$ were significantly lower $(P<0.05)$ for $T$. axei and Trichostrongylus spp. in nematodes from goats under the higher stocking rate. The fertility of Teladorsagia circumcincta tended to be higher in worms from goats under the high stocking rate, particularly in those from supplemented goats. In general, the number and length of male worms tended to be lower in goats under the higher stocking rate and supplemented with heather.

\section{Mortality of Goats}

A total of nine goats died between September and October, eight animals on plots with 38 goats $\cdot$ ha $^{-1}$ (three supplemented and five nonsupplemented with heather) and one supplemented goat from the plot with 24 goats $\cdot \mathrm{ha}^{-1}$. Although the mortality rate tended to be higher $(P=0.057)$ in goats under the high stocking rate, no significant differences were associated with heather supplementation $(P>0.10)$.

\section{Live Weight and Body Condition Changes}

The effect of stocking rate on LW changes only was significant $(P<0.001)$ for the second period of the grazing season (Table 4). In the first period, goats under the low stocking rate gained only $7 \mathrm{~g} \cdot \mathrm{d}^{-1}$ more than goats under the high stocking rate, whereas they lost $46 \mathrm{~g} \cdot \mathrm{d}^{-1}$ less in the second period. On the other hand, heather supplementation significantly affected LW changes, both in the first $(P<0.05)$ and second $(P<0.01)$ grazing periods. Goats receiving heather supplementation gained $17 \mathrm{~g} \cdot \mathrm{d}^{-1}$ more in the first period and lost $21 \mathrm{~g} \cdot \mathrm{d}^{-1}$ less in the second period than nonsupplemented goats.

LW changes for the overall grazing season were significantly $(P<0.001)$ affected by the stocking rate (gains of 30 vs. $9 \mathrm{~g} \cdot \mathrm{d}^{-1}$ for low and high, respectively) and heather supplementation (gains of 28 vs. $11 \mathrm{~g} \cdot \mathrm{d}^{-1}$ for supplemented and nonsupplemented goats). The interaction of stocking rate $\times$ heather supplementation was not significant, although a tendency $(P<0.10)$ was observed in the second period, with 
Table 2. Mean worm burden (counts $\cdot$ goat $^{-1}$ ), sex ratio (male:female) and fecundity in utero (eggs $\cdot$ female ${ }^{-1}$ ) of abomasal and intestinal nematodes in goats under different stocking rates (low or high) and supplemented or nonsupplemented (yes or no, respectively) with heather.

\begin{tabular}{|c|c|c|c|c|c|}
\hline & \multicolumn{2}{|c|}{ Low (24 goats $\cdot$ ha $^{-1}$ ) } & \multicolumn{2}{|c|}{ High (38 goats $\cdot$ ha $^{-1}$ ) } & \multirow[b]{2}{*}{ SEM } \\
\hline & No & Yes & No & Yes & \\
\hline Abomasum (total) & $4477 a b^{1}$ & $3476 \mathrm{~b}$ & $6998 a$ & $3693 \mathrm{~b}$ & 1003 \\
\hline \multicolumn{6}{|c|}{ Teladorsagia circumcincta } \\
\hline Worm burden & $4129 a b$ & $3172 b$ & $6209 \mathrm{a}$ & $3099 \mathrm{~b}$ & 922 \\
\hline Sex ratio & $0.76 \mathrm{a}$ & $0.78 \mathrm{a}$ & $0.66 \mathrm{~b}$ & $0.68 \mathrm{~b}$ & 0.044 \\
\hline Fecundity in utero & $6.6 \mathrm{~b}$ & $5.6 \mathrm{~b}$ & $7.7 \mathrm{ab}$ & $9.5 \mathrm{a}$ & 0.78 \\
\hline \multicolumn{6}{|l|}{ Trichostrongylus axei } \\
\hline Worm burden & $348 \mathrm{~b}$ & $304 \mathrm{~b}$ & $789 a$ & 594 a & 173 \\
\hline Sex ratio & $0.10 \mathrm{~b}$ & $0.76 \mathrm{a}$ & $0.14 \mathrm{~b}$ & $0.92 \mathrm{a}$ & 0.094 \\
\hline Fecundity in utero & $15.4 \mathrm{a}$ & $13.1 \mathrm{a}$ & $10.0 \mathrm{~b}$ & $9.4 \mathrm{~b}$ & 1.08 \\
\hline Small intestine (total) & $7671 \mathrm{~b}$ & 7077 b & $24733 \mathrm{a}$ & 24592 a & 3538 \\
\hline \multicolumn{6}{|l|}{ Trichostrongylus spp. } \\
\hline Worm burden & $7671 \mathrm{~b}$ & 7077 b & $24733 \mathrm{a}$ & 24592 a & 3538 \\
\hline Sex ratio & $0.91 \mathrm{a}$ & $0.90 \mathrm{a}$ & $0.85 a b$ & $0.80 \mathrm{~b}$ & 0.036 \\
\hline Fecundity in utero & $18.8 \mathrm{a}$ & $14.8 \mathrm{a}$ & $11.2 \mathrm{~b}$ & $9.6 \mathrm{~b}$ & 1.30 \\
\hline Large intestine (total) & 24.8 & 25.6 & 26.6 & 28.5 & 8.22 \\
\hline \multicolumn{6}{|l|}{ Chabertia ovina } \\
\hline Worm burden & $0.4 \mathrm{~b}$ & $0.8 \mathrm{~b}$ & $17.6 \mathrm{a}$ & $6.5 \mathrm{~b}$ & 2.07 \\
\hline \multicolumn{6}{|c|}{ Oesophagostomum columbianum } \\
\hline Worm burden & 10.8 & 7.0 & 4.6 & 6.8 & 3.06 \\
\hline \multicolumn{6}{|l|}{ Trichuris ovis } \\
\hline Worm burden & 13.6 & 17.8 & 4.1 & 15.2 & 7.83 \\
\hline
\end{tabular}

${ }^{1}$ Means followed by different letters in the same row are significantly different $(P<0.05)$.

nonsupplemented goats under the high stocking rate showing the greatest weight loss $\left(-117 \mathrm{~g} \cdot \mathrm{d}^{-1}\right)$.

Body condition was affected by stocking rate in a similar way to LW changes $(P<0.001)$. However, the effect of heather supplementation was not statistically significant in any period (Table 4).

\section{Correlations}

The study of the relationships between the heather consumption by goats and their parasite burden and performance

Table 3. Mean length $(\mathrm{mm})$ of abomasal and intestinal nematodes in goats under different stocking rates (low or high) and supplemented or nonsupplemented (yes or no, respectively) with heather.

\begin{tabular}{|c|c|c|c|c|c|}
\hline & \multicolumn{2}{|c|}{ Low (24 goats $\cdot$ ha $\left.^{-1}\right)$} & \multicolumn{2}{|c|}{ High (38 goats $\cdot$ ha $\left.^{-1}\right)$} & \multirow[b]{2}{*}{ SEM } \\
\hline & No & Yes & No & Yes & \\
\hline \multicolumn{6}{|c|}{ Teladorsagia circumcincta } \\
\hline Female & $7.21 b^{1}$ & $7.63 \mathrm{a}$ & $6.98 \mathrm{~b}$ & $7.66 \mathrm{a}$ & 0.182 \\
\hline Male & $5.88 \mathrm{a}$ & $5.90 \mathrm{a}$ & $5.61 \mathrm{~b}$ & $5.40 \mathrm{~b}$ & 0.128 \\
\hline \multicolumn{6}{|c|}{ Trichostrongylus axei } \\
\hline Female & $5.88 \mathrm{a}$ & $5.98 \mathrm{a}$ & $5.28 \mathrm{~b}$ & $5.11 \mathrm{~b}$ & 0.195 \\
\hline Male & $4.66 \mathrm{a}$ & $4.74 \mathrm{a}$ & $4.20 \mathrm{~b}$ & $4.13 \mathrm{~b}$ & 0.153 \\
\hline \multicolumn{6}{|c|}{ Trichostrongylus spp. } \\
\hline Female & $6.50 \mathrm{a}$ & $6.43 \mathrm{a}$ & $5.92 \mathrm{ab}$ & $5.55 \mathrm{~b}$ & 0.189 \\
\hline Male & 5.14 & 4.95 & 4.64 & 4.70 & 0.183 \\
\hline
\end{tabular}

showed a significant positive correlation $(r=0.39, P<0.01)$ between LW changes during the grazing season and the percentage of heather in the diet, which ranged from $10 \%$ to $45 \%$ in the supplemented goats. The correlations were significant for both low $(r=0.56, P<0.01)$ and high $(r=0.47, P<0.01)$ stocking rates. On the other hand, significant negative correlations $(r=-0.59, P<0.001)$ were found between LW changes and FEC in October. No significant relationship between the percentage of heather in the diet and FEC was observed.

\section{DISCUSSION}

Although the results reported in the literature are not consistent, a significant effect of the stocking rate on GIN infection was observed in this study. In the second half of the grazing season (period 2), FEC increased considerably under the high stocking rate (from 360-470 epg in August to 4100 4800 epg in October), whereas the increase was more limited at the low stocking rate (from 300 epg to 1500 epg). This effect of stocking rate on FEC was in accordance with previous results obtained in angora goats naturally infected with Teladorsagia circumcincta and Haemonchus contortus (Le Jambre 1984) and in grazing sheep (Thamsborg et al. 1996). Hansen et al. (1989) also found in beef heifers that the lowest stocking rate groups continuously had the lowest GIN egg output and serum pepsinogen levels. Animals at higher stocking rates are forced to graze closer to the manure, and they 
Table 4. Effects of stocking rate (low or high) and heather supplementation (yes indicates supplemented; no, nonsupplemented) on goat live weight (LW) and body condition score (BCS) changes during the grazing season.

\begin{tabular}{|c|c|c|c|c|c|c|c|c|}
\hline & \multicolumn{2}{|c|}{ Low (24 goats $\cdot$ ha $\left.^{-1}\right)$} & \multicolumn{2}{|c|}{ High (38 goats $\cdot$ ha $^{-1}$ ) } & \multirow[b]{2}{*}{ SEM } & \multicolumn{3}{|c|}{ Significance } \\
\hline & Yes & No & Yes & No & & $\mathrm{SR}^{1}$ & $\mathrm{H}$ & $\mathrm{SR} \times \mathrm{H}$ \\
\hline Initial LW (kg) & 24.6 & 25.7 & 22.1 & 22.9 & 0.53 & * & NS & NS \\
\hline Initial BCS (scale 1 to 5 ) & 2.8 & 2.7 & 2.7 & 2.6 & 0.03 & NS & NS & NS \\
\hline \multicolumn{9}{|l|}{ LW change $\left(g \cdot d^{-1}\right)$} \\
\hline Period $1^{2}$ & 95 & 68 & 78 & 72 & 3.3 & NS & * & NS \\
\hline Period $2^{3}$ & -51 & -61 & -86 & -117 & 4.6 & $* * *$ & $* *$ & NS \\
\hline Overall $^{4}$ & 40 & 20 & 15 & 2 & 2.8 & $\star * *$ & $* \star *$ & NS \\
\hline \multicolumn{9}{|l|}{ BCS change (scale units) } \\
\hline Period $1^{2}$ & 0.3 & 0.3 & 0.2 & 0.3 & 0.03 & NS & NS & NS \\
\hline Period $2^{3}$ & 0.1 & 0.0 & -0.5 & -0.5 & 0.38 & $\star * *$ & NS & NS \\
\hline Overall $^{4}$ & 0.4 & 0.3 & -0.3 & -0.2 & 0.45 & $\star * *$ & NS & NS \\
\hline
\end{tabular}

${ }^{1} \mathrm{SR}$ indicates stocking rate; $\mathrm{H}$, heather supplementation.

${ }^{2}$ From 6 May to 19 August.

${ }^{3}$ From 19 August to 21 October

${ }^{4}$ From 6 May to 21 October.

${ }^{\star} P<0.05,{ }^{* *} P<0.01,{ }^{* *} P<0.001$, NS indicates not significant $(P>0.05)$.

inevitably ingest a larger number of infective nematode larvae. In general, a higher stocking rate means higher GIN egg output and dispersion and therefore higher pasture contamination and infection risk. In addition, mountain pastures have a higher density than those in lowlands, and the development and persistence of third-stage trichostrongylid larvae is higher in denser pastures (Moss and Bray 2006). A high stocking rate also means a shorter palatable sward height, less options to select grazing areas when rejecting those contaminated by feces, lower intake, and even negative nutritive balances (Morley and Donald 1980).

Contrary to previous studies in the same experimental farm (Osoro et al. 2007a, 2007b), in the present trial no significant differences in FEC were detected between goats supplemented with tannin-containing heather and those nonsupplemented. The lack of significant differences in the current study could be due to the lower nematode burden when compared to previous grazing seasons, which was probably caused by an anomalous dry year. In previous studies (Osoro et al. 2007b), the mean FEC at the end of the grazing season in the nonsupplemented group, which was managed under a lower stocking rate, was 8600 epg compared to 1500 epg and 4500 epg observed in the present trial under low and high stocking rates, respectively, in nonsupplemented goats. Climatic conditions are known to affect GIN larvae survival and migration in the environment and subsequently the intensity of infection. The dispersal of larvae from feces is largely dependent on sufficient water from dew or rainfall to allow migration (Stromberg 1997).

The FEC kinetics over the grazing season and GIN genera identified in coprocultures confirmed previous epidemiological data obtained in the same goat research farm (Osoro et al. 2007b).

Our results showed a significant effect of stocking rate on Trichostrongylus spp. but not on Teladorsagia circumcincta worm burdens. These results are in agreement with those reported by Thamsborg and Hauge (2001), who observed higher FEC and worm burdens in grazing weaned lambs naturally infected with T. circumcincta and Trichostrongylus vitrinus at a high stocking rate when compared with animals at low or medium stocking rates. In the current work, heather supplementation reduced $T$. circumcincta burden, but this effect was only significant in goats under the high stocking rate. It is also noteworthy that fecundity in utero and length of $T$. circumcincta females in supplemented goats were higher than those observed in nonsupplemented animals, probably indicating a long-term established population. Thus, heather could affect the development of the incoming third-stage T. circumcincta larvae. A reduction of $70 \%$ in worm numbers was observed by Paolini et al. (2003) in goats receiving condensed tannins before being infected with third-stage larvae of $T$. circumcincta.

In this trial, heather supplementation had a positive effect on LW changes and reduced GIN effects when animals were managed under the high stocking rate. Previous studies have reported the effect of protein on host resilience to GIN infection (van Houtert and Sykes 1996; Chartier et al. 2000). However, in contrast to other protein-rich tannin-containing legumes, such as Lotus corniculatus L., used in other studies (Marley et al. 2003; Athanasiadou et al. 2006), heather has a low protein content (approx. $70 \mathrm{~g} \mathrm{CP} \cdot \mathrm{kg}^{-1} \mathrm{DM}$ ), and therefore the positive responses to its supplementation cannot be attributed to the effect of a dietary protein increase. Nevertheless, heather supplementation could have a positive influence on other aspects of protein metabolism, such as reducing ruminal protein degradation through the action of tannins (Frutos et al. 2000).

The positive effect of supplementation of heather and forage containing condensed tannins on animal performance was previously observed in grazing cashmere (Osoro et al. 2007a, 2007b) and angora goats (Min et al. 2005). In the current study, goats under the high stocking rate had significantly worse LW changes in the second half of the grazing season when the available mean sward height was below $8 \mathrm{~cm}$. These results are consistent with the linear relationship observed between green sward height and LW changes in cashmere goats grazing pastures with sward height between $3 \mathrm{~cm}$ and $11 \mathrm{~cm}$ 
(Merchant and Riach 1994; Osoro et al. 2000), or between $6 \mathrm{~cm}$ and $11 \mathrm{~cm}$ in feral $\times$ angora goats (Radcliffe et al. 1991). A restriction of goats' performance in pastures with sward height lower than $7 \mathrm{~cm}$ was reported by McCall and Lambert (1987). The absence of significant differences in LW changes during the first period would be a consequence of the high sward height $(13.1 \mathrm{~cm} \pm 1.08)$ not limiting herbage intake. The higher LW gains $\left(68-95 \mathrm{~g} \cdot \mathrm{d}^{-1}\right)$ observed in this study during the first period in comparison with a previous work carried out in the same farm (Osoro et al. 2007b), where goats had higher sward height available $(19.5 \mathrm{~cm} \pm 3.10)$ but lower LW gains (17$\left.50 \mathrm{~g} \cdot \mathrm{d}^{-1}\right)$, is an indicator of the effect of pasture quality and climatic conditions on LW changes. It is known that, according to pasture dynamics, there is an increase of pasture senescence associated with the increase in sward height (Bircham and Hodgson 1983; Hodgson 1985), with goats showing preference for green pastures (Merchant and Riach 1994).

The interaction between nutrition, GIN infection, and LW changes has been well discussed both in sheep (Houdijk and Athanasiadou 2003) and goats (Hoste et al. 2005). It has been suggested that the severity of disease and the loss of production depend upon the intensity of infection, the host immunity, and the hosts relative nutritional status (Coop and Kyriazakis 2001).

The positive correlation coefficient between the heather percentage in the diet and the LW changes during the experimental grazing season in both stocking rates is in agreement with our previous results $(r=0.54$; Osoro et al. 2007b), and points again to the beneficial effects of heather availability on goats' performance.

\section{IMPLICATIONS}

The high stocking rate increased the infection risk at pasture, and the supplementation of grazing goats with tannincontaining heather improved animal performance, but did not reduce the FEC under the dry climatic conditions of the study year. Practical application of this knowledge in temperate areas supports the management of plots integrating productive improved pastures with high nutritive value (ryegrass-white clover) with natural vegetation communities including tannincontaining plants, such as heather species, as previously suggested (Osoro et al. 1999; Kahiya et al. 2003). Improved pastures could be used to improve protein and energy intake, and natural vegetation for fibre, minerals, and secondary compounds (condensed tannins) that contribute to improve animal welfare and performance to achieve sustainable goat production systems.

\section{ACKNOWLEDGMENTS}

We thank the staff of the experimental farm for their work in the management of the animals and field sampling, and A. Mateos for her technical assistance.

\section{LITERATURE CITED}

Association of Official Analytical Chemists. 2006. Official methods of analysis. 18th ed. (1st revision). Gaithersburg, MD, USA: AOAC. 2200 p.
Athanasiadou, S., I. Kyriazakis, and F. Jackson. 2006. Can plant secondary metabolites have a role in controlling gastrointestinal nematode parasitism in small ruminants? In: C. A. Sandoval-Castro, F. D. De B. Hovell, J. F. J. TorresAcosta, and A. Ayala-Burgos [EDs.]. Herbivores: the assessment of intake, digestibility and the roles of secondary compounds. Nottingham, United Kingdom: British Society of Animal Science. p. 197-207.

BARGER, I. A. 1999. The role of epidemiological knowledge and grazing management for helminth control in small ruminants. International Journal of Parasitology 29:41-47.

Barthram, G. T. 1986. Experimental techniques: the HFRO swardstick. In: The Hill Farming Research Organisation Biennial Report, 1984-1985. Bush Estate, Penicuik, Midlothian, Scotland, United Kingdom: Hill Farming Research Organisation. p. 29-30.

Bircham, J. S., AND J. HodgSON. 1983. The influence of sward condition on rates of herbage growth and senescence in mixed swards under continuous stocking management. Grass and Forage Science 38:323-331.

Chartier, C., E. Etter, H. Hoste, I. Pors, M.-P. Mallereau, C. Broqua, S. Mallet, C. KoCH, AND A. Massé. 2000. Effects of the initial level of milk production and of the dietary protein intake on the course of natural nematode infection in dairy goats. Veterinary Parasitology 92:1-13.

Coop, R. L., AND I. KYriazAKIS. 2001. Influence of host nutrition on the development and consequences of nematode parasitism in ruminants. Trends in Parasitology 17:325-330.

Dove, H., AND A. D. Moore. 1995. Using a least-squares optimisation procedure to estimate diet composition based on the alkanes of plant cuticular wax. Australian Journal of Agricultural Research 46:1535-1544.

Ferreira, L. M. M., M. Oliván, U. García, M. A. M. Rodrigues, and K. Osoro. 2005. Validation of the alkane technique to estimate diet selection of goats grazing heather-gorse vegetation communities. Journal of the Science of Food and Agriculture 85:1636-1646.

Frutos, P., G. Hervás, F. J. Giráldez, M. Fernández, and A. R. Mantecón. 2000. Digestive utilisation of quebracho treated soya bean meals in sheep. Journal of Agricultural Science 134:101-108.

Goening, M. K., and P. J. van Soest. 1970. Forage fiber analysis (apparatus, reagents, procedures and some applications). Washington, DC, USA: US Department of Agriculture, Agricultural Research Service, Agricultural Handbook No. 379. 19 p.

Grant, S. A. 1981. Sward components. In: J. Hodgson, R. D. Baker, A. Davies, A. S. Laidlaw, and J. D. Leaver [EDS.]. Sward measurement handbook. Hurley, Maidenhead, Berkshire, United Kingdom: British Grassland Society. p. 71-92.

Hansen, J. W., A. M. Zajac, D. E. Eversole, and H. J. Gerken. 1989. The effect of stocking rate and parasite control on the performance of replacement beef heifers on pasture. Veterinary Parasitology 34:103-113.

Hodgson, J. 1985. The control of herbage intake in the grazing ruminant. Proceedings of the Nutrition Society 44:339-346.

Hoste, H., F. Jackson, S. Athanasiadou, S. M. Thamsborg, and S. 0. Hoskin. 2006. The effects of tannin-rich plants on parasitic nematodes in ruminants. Trends in Parasitology 22:253-261.

Hoste, H., J. F. Torres-Acosta, V. Paolini, A. Aguilar-Caballero, A. Etter, Y. Lefrileux, C. Chartier, and C. Broqua. 2005. Interactions between nutrition and gastrointestinal infections with parasitic nematodes in goats. Small Ruminant Research 60:141-151.

HoudiJk, J. G. M., And S. Athanasiadou. 2003. Direct and indirect effects of host nutrition on ruminant gastrointestinal nematodes. In: L. t'Mannetje, L. RamírezAvilés, C. Sandoval-Castro, and J. C. Ku-Vera [EDS.]. Matching herbivore nutrition to ecosystems biodiversity. VI International Symposium on the Nutrition of Herbivores. Mérida, Yucatán, México: Universidad Autónoma de Yucatán. p. 213-236.

JaCKson, F., And R. L. Coop. 2000. The development of anthelmintic resistance in sheep nematodes. Parasitology 120:95-107.

Kahiya, C., S. Mukaratirwa, and S. M. Thamsborg. 2003. Effects of Acacia nilotica and Acacia karoo diets on Haemonchus contortus infection in goats. Veterinary Parasitology 115:265-274.

Kloosterman, A., G. A. A. Albers, and H. Van Den Brink. 1978. Genetic variations among calves in resistance to nematode parasites. Veterinary Parasitology 4:353-368. 
Le JamBre, L. F. 1984. Stocking rate effects on the worm burdens of angora goats and merino sheep. Australian Veterinary Journal 61:280-282.

Littell, R. C., P. R. Henry, and C. B. Ammerman. 1998. Statistical analysis of repeated measures data using SAS procedures. Journal of Animal Science 76:1216-1231.

[MAFF] Ministry of Agriculture, Fisheries, and Food. 1978. Manual of veterinary parasitological techniques. London, United Kingdom: MAFF, Technical Bulletin No. 18.129 p.

MakKar, H. P. S., M. Blummel, N. K. Borowy, and K. Becker. 1993. Gravimetric determination of tannins and their correlations with chemical and protein precipitation methods. Journal of the Science of Food and Agriculture 61:161-165.

Marley, C. L., R. Cook, R. Keatinge, J. Barret, and N. H. Lampkin. 2003. The effect of birdsfoot trefoil (Lotus corniculatus) and chicory (Cichorium intybus) on parasite intensities and performance of lambs naturally infected with helminth parasites. Veterinary Parasitology 112:147-155.

Mayes, R. W., C. S. Lamb, and P. M. Colgrove. 1986. The use of dosed and herbage $n$-alkanes as markers for the determination of herbage intake. Journal of Agricultural Science 107:161-170.

McCall, D. G., and M. G. Lambert. 1987. Pasture feeding of goats. In: A. M. Nicol [ED.]. Livestock feeding on pasture. Hamilton, New Zealand: New Zealand Society of Animal Production, Occasional Publication No. 10. p. 105-109.

Merchant, M., and D. J. Riach. 1994. The intake and performance of cashmere goats grazing sown swards. Grass and Forage Science 49:429-437.

MiLne, J., AND K. Osoro. 1997. The role of livestock in habitat management. In: J. P. Laker and J. A. Milne [EDS.]. Livestock systems in European rural development. Proceedings of the 1st Conference of the LSIRD network, Nafplio, Greece. Craigiebuckler, Aberdeen, Scotland, United Kingdom: Macaulay Land Use Research Institute. p. 75-80.

Min, B. R., S. P. Hart, D. Miller, G. M. Tomita, E. Loetz, and T. Sahlu. 2005. The effect of grazing forage containing condensed tannins on gastro-intestinal parasite infection and milk composition in Angora does. Veterinary Parasitology 130:105-113.

Morley, F. H. W., and A. D. Donald. 1980. Farm management and systems of helminth control. Veterinary Parasitology 6:105-134.

Moss, R. A., And A. R. Bray. 2006. Effect of sward density and size of faecal deposit on the development and persistence of third-stage Trichostrongylid larvae of sheep. New Zealand Journal of Agricultural Research 49:475-481.

OLIVÁn, M., AND K. Osoro. 1999. Effect of temperature on alkane extraction from faeces and herbage. Journal of Agricultural Science 132:305-312.

Osoro, K., A. Benito-Peña, P. Frutos, U. García, L. M. Ortega-Mora, R. Celaya, and I. FerRE. 2007a. The effect of heather supplementation on gastrointestinal nematode infections and performance in Cashmere and local Celtiberic goats on pasture. Small Ruminant Research 67:184-191.

Osoro, K., R. Celaya, and A. Martínez. 2000. The effect of grazing management of sheep and goats on animal performance and vegetation dynamics in partially improved heath-gorse vegetation. In: A. J. Rook and P. D. Penning [EDs.]. Grazing management. Reading, United Kingdom: British Grassland Society, Occasional Symposium No. 34. p. 135-140.

Osoro, K., And A. Martínez. 1995. Grazing behaviour and performance of goats and sheep on natural and improved vegetation. In: J. P. Laker and A. J. F. Russel [EDS.]. The nutrition and grazing ecology of speciality fibre producing animals. Craigiebuckler, Aberdeen, Scotland, United Kingdom: Macaulay Land Use Research Institute, European Fine Fibre Network Occasional Publication No. 3. p. $109-125$.
Osoro, K., A. Mateos-Sanz, P. Frutos, U. García, L. M. Ortega-Mora, L. M. M. Ferreira, R. Celaya, and I. Ferre. 2007b. Anthelmintic and nutritional effects of heather supplementation on Cashmere goats grazing perennial ryegrass-white clover pastures. Journal of Animal Science 85:861-870.

Osoro, K., J. M. Vassallo, R. Celaya, and A. Martínez. 1999. Livestock production systems and the vegetation dynamics of Less Favoured Areas (LFAs): developing viable systems to manage semi-natural vegetation in temperate LFAs in Spain. In: J. P. Laker and J. A. Milne [EDS.]. Livestock production in the European Less Favoured Areas: meeting future economic, environmental, and policy objectives through integrated research. Proceedings of the 2nd conference of the LSIRD network, Bray, Dublin, Ireland. Craigiebuckler, Aberdeen, Scotland, United Kingdom: Macaulay Land Use Research Institute. p. 133-143.

Paolini, V., A. Frayssines, F. De La Farge, P. Dorchies, and H. Hoste. 2003. Effects of condensed tannins on established populations and on incoming larvae of Trichostrongylus colubriformis and Teladorsagia circumcincta in goats. Veterinary Research 34:331-339.

Radcliffe, J. E., R. J. Townsend, and D. B. Baird. 1991. Mixed and separate grazing of sheep and goats at two stocking rates. New Zealand Journal of Agricultural Research 34:167-176.

Russel, A. J. F. 1990. Body condition scoring of goats. Scottish Cashmere Producers Association Newsletter 10:3.

SAS InstITUTE. 1999. SAS/STAT user's guide, V8. Cary, NC, USA: SAS Institute, Inc. $3884 \mathrm{p}$.

Shaik, S. A., T. H. Terrill, J. E. Miller, B. Kouakou, G. Kannan, R. M. Kaplan, J. M. BuRKE, AND J. A. Mosudiss. 2006. Sericea lespedeza hay as a natural deworming agent against gastrointestinal nematode infection in goats. Veterinary Parasitology 9:150-157.

Stear, M. J., M. Doligaska, and K. Donskow-Schmelter. 2007. Alternatives to anthelmintics for the control of nematodes in livestock. Parasitology 134:139-151.

Stromberg, B. E. 1997. Environmental factors influencing transmission. Veterinary Parasitology 72:247-264.

Thamsborg, S. M., and E. M. Hauge. 2001. Osteopenia and reduced serum alkaline phosphatase activity in grazing lambs naturally infected with gastrointestinal nematodes. Journal of Comparative Pathology 125:192-203.

Thamsborg, S. M., R. J. Jørgensen, P. J. Waller, and P. Nansen. 1996. The influence of stocking rate on gastrointestinal nematode infections of sheep over a 2-yr grazing period. Veterinary Parasitology 67:207-224.

van Houtert, M. F. J., And A. R. Sykes. 1996. Implications of nutrition for the ability of ruminants to withstand gastrointestinal nematode infections. International Journal of Parasitology 26:1151-1167.

van Soest, P. J., J. B. Robertson, and B. A. Lewis. 1991. Methods for dietary fiber, neutral detergent fiber, and nonstarch polysaccharides in relation to animal nutrition. Journal of Dairy Science 74:3583-3597.

van Wyk, J. A., J. Cabaret, and L. M. Michael. 2004. Morphological identification of nematode larvae of small ruminants and cattle simplified. Veterinary Parasitology 119:277-306.

Waller, P. J. 2006. Sustainable nematode parasite control strategies for ruminant livestock by grazing management and biological control. Animal Feed Science and Technology 126:277-289.

Wang, Z., and L. A. Goonewardene. 2004. The use of MIXED models in the analysis of animal experiments with repeated measures data. Canadian Journal of Animal Science 84:1-11. 